\title{
PENERAPAN MODEL PEMBELAJARAN KOOPERATIF TIPE TGT DENGAN MEDIA KARTU KATA UNTUK MENINGKATKAN MOTIVASI BELAJAR DAN KEMAMPUAN MEMBACA
}

\author{
Nyoman Dantes ${ }^{1, *}$, Ketut Dharsana ${ }^{2}$, Gst. N. Sutrisna 3 \\ 1 Jurusan Bimbingan Konseling. Universitas Pendidikan Ganesha, Indonesia \\ 2 Jurusan Bimbingan Konseling. Universitas Pendidikan Ganesha, Indonesia \\ ${ }^{3}$ Jurusan Pendidikan Guru Sekolah Dasar. Universitas Pendidikan Ganesha, Indonesia
}

\begin{abstract}
Abstrak
Penelitian ini bertujuan untuk meningkatkan motivasi belajar dan kemampuan membaca siswa kelas II semester 2 SD No. 2 Penarukan setelah diterapkan model pembelajaran kooperatif tipe TGT dengan media kartu kata dalam pembelajaran Bahasa Indonesia. Proses pengumpulan data motivasi belajar siswa dikumpulkan dengan menggunakan angket motivasi belajar dan data kemampuan membaca siswa diperoleh melalui tes membaca. Berdasarkan hasil analisis, pada siklus I skor ratarata motivasi siswa adalah 30,83 (kategori cukup tinggi) dan pada siklus II meningkat menjadi 39,77 (kategori tinggi), maka terjadi peningkatan dari siklus I ke siklus II sebesar 8,94. Pada siklus I skor rata-rata kemampuan membaca siswa adalah 65,86 (kategori tinggi) dan pada siklus II meningkat menjadi 72,13 (kategori tinggi), maka terjadi peningkatan kemampuan membaca dari siklus I ke siklus II sebesar 6,27. Implikasi dari penelitian ini bahwa penerapan model pembelajaran kooperatif tipe TGTdengan media kartu kata dalam pembelajaran Bahasa Indonesia dapat meningkatkan motivasi belajar dan kemampuan membaca siswa kelas II semester II di SD No. 2 Penarukan.
\end{abstract}

\author{
Keywords: \\ pembelajaran kooperatif \\ tipe TGT, motivasi dan \\ kemampuan membaca
}

\section{Pendahuluan}

Sudah sewajarnya dalam pembelajaran Bahasa Indonesia di SD siswa tidak hanya diajak untuk memahami aspek-aspek keterampilan Bahasa Indonesiayang berujung siswa menjadi kurang termotivasi untuk belajar Bahasa Indonesia. Jika motivasi belajar tidak ada dalam diri mereka atau datang dari lingkungan siswa, maka tidak mungkin siswa dapat berpartisipasi dengan baik dalam pembelajaran Bahasa Indonesia apalagi untuk belajar membaca, karena untuk belajar saja mereka enggan. Rendahnya motivasi belajar dan kemampuan membaca siswa terlihat pada mata pelajaran Bahasa Indonesia karena masih ditemukan adanya kesulitan belajar siswa, salah satunya yaitu kemampuan siswa dalam membaca bacaan pendek dengan menggunakan lafal dan intonasi yang baik dan benar ternyata kemampuan siswa masih sangat rendah, serta kurangnya media yang mendukung dalam proses pembelajaran khususnya media kartu kata. Hal itulah yang menjadi hambatan bagi siswa untuk meningkatkan motivasi belajar dan kemampuannya dalam membaca permulaan.

Kenyataan di lapangan menunjukkan bahwa motivasi belajar dan kemampuan membaca siswa masih rendah. Hal itu dapat dilihat dari hasil observasi data awal siswa pada mata pelajaran Bahasa Indonesia yang dilakukan terhadap siswa kelas II semester II di SD No. 2 Penarukan.Ditemukan bahwa dari 30 siswa kelas II, hanya 12 orang yang menunjukkan kemampuan membaca permulaan yang sudah memenuhi kriteria keberhasilan.Namun kemampuan membaca permulaan siswa lainnya masih belum memenuhi kriteria keberhasilan.Itu terlihat dari nilai kemampuan membaca siswa masih di bawah ratarata atau belum memenuhi standar KKM (Kriteria ketuntasan Minimal) yang ditentukan.Hal itu dapat dilihat pada tabel 1 . 
Tabel 1 Daftar Skor Awal Kelas II Semester II SD No. 2 Penarukan Mata Pelajaran Bahasa Indonesia

\begin{tabular}{|c|c|c|c|c|}
\hline No & Nama Siswa & $\begin{array}{c}\text { Daftar Skor } \\
\text { Data Awal }\end{array}$ & KKM & Ket \\
\hline 1 & Komang Agus Setiawan & 66 & 61 & $\mathrm{~T}$ \\
\hline 2 & Ketut Ayu Rindiyani & 64 & 61 & $\mathrm{~T}$ \\
\hline 3 & Luh Pt. Arderima Chintyana & 54 & 61 & BT \\
\hline 4 & Gede Sukrama & 52 & 61 & BT \\
\hline 5 & Kadek Vina Cahyuni & 64 & 61 & $\mathrm{~T}$ \\
\hline 6 & Ni Kd. Intan Kusuma M D & 60 & 61 & BT \\
\hline 7 & Desak Kd. Rita Rianti & 52 & 61 & BT \\
\hline 8 & Desak Kd. Juliana & 58 & 61 & BT \\
\hline 9 & Desak Kd. Sri Mahendri & 58 & 61 & BT \\
\hline 10 & Desak Km. Linda Perawati & 54 & 61 & BT \\
\hline 11 & I Ketut Noviani & 58 & 61 & BT \\
\hline 12 & Kd. Ari Wira Pratama & 64 & 61 & $\mathrm{~T}$ \\
\hline 13 & Km. Risky Saputra & 52 & 61 & BT \\
\hline 14 & Ketut Agustini & 58 & 61 & BT \\
\hline 15 & Km. Suhendra Wirawan & 68 & 61 & $\mathrm{~T}$ \\
\hline 16 & Ni Luh Budi Ari Ayu & 60 & 61 & BT \\
\hline 17 & Putu Agus Satria Darma & 58 & 61 & BT \\
\hline 18 & Ketut Mai Astari & 66 & 61 & $\mathrm{~T}$ \\
\hline 19 & Dw. Md. Eka Saputra & 60 & 61 & BT \\
\hline 20 & Komang Ayu Indrayani & 68 & 61 & $\mathrm{~T}$ \\
\hline 21 & Desak Pt. Listia Septiani & 54 & 61 & BT \\
\hline 22 & Desak Komang Lestari & 56 & 61 & BT \\
\hline 23 & Dewa Komang Dodi S & 64 & 61 & $\mathrm{~T}$ \\
\hline 24 & Gd Suardika & 58 & 61 & BT \\
\hline 25 & Luh Desi Anggarini & 62 & 61 & $\mathrm{~T}$ \\
\hline 26 & Gede Panca Darmayasa & 64 & 61 & $\mathrm{~T}$ \\
\hline 27 & Kd. Ayu Adiningsih & 54 & 61 & BT \\
\hline 28 & Putu Bagiasta & 60 & 61 & BT \\
\hline 29 & Gede Alit Mertadana & 68 & 61 & $\mathrm{~T}$ \\
\hline \multirow[t]{3}{*}{30} & Ni Putu Nonik Septiyanti & 64 & 61 & $\mathrm{~T}$ \\
\hline & Total & 1798 & & \\
\hline & Rata-rata & 59,93 & & \\
\hline
\end{tabular}

(Sumber: Guru Kelas II Semester II SD No. 2 Penarukan)

Dari data skor di atas dapat dilihat sekitar $60 \%$ siswa mendapat nilai di bawah standar KKM dan sekitar $40 \%$ siswa kelas II semester II yang mampu mencapai standar KKM mata pelajaran Bahasa Indonesia yang ditetapkan SD No. 2 Penarukan. Secara umum hasil data awal di atas dapat dilihat pada gambar diagram 1 di bawah ini.

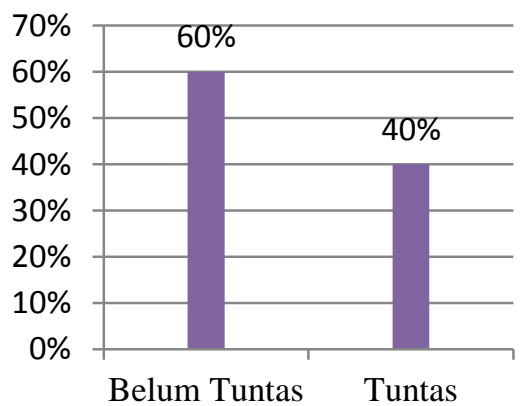

Gambar 1. Diagram Ketuntasan Belajar

Selain itu, berdasarkan hasil observasi dan wawancara dengan guru kelas II semester II di SD No. 2 Penarukan ditemukan permasalahan sebagai berikut. (1) Pembelajaran Bahasa Indonesia di sekolah tersebut masih menggunakan model pembelajaran yang konvesional yakni suatu model pembelajaran yang banyak didominasi oleh guru, sementara siswa duduk secara pasif menerima informasi pengetahuan 
dan keterampilan. (2) Kurangnya penggunaan atau pemanfaatan media dalam pembelajaran, sehingga siswa sulit memahami apa yang akan dipelajari. (3) Siswa kurang antusias menerima pelajaran karena dalam proses penyajian materi belum menggunakan model pembelajaran yang sesuai. Hal itulah yang diduga menjadi hambatan bagi siswa untuk meningkatkan motivasi belajar dan kemampuannya dalam membaca, sehingga keadaan ini memerlukan perbaikan dan inovasi dalam pembelajaran.

Melihat permasalahan tersebut, maka perlu diterapkan suatu model pembelajaran yang melibatkan peran siswa secara aktif dalam proses pembelajaran. Salah satu model pembelajaran yang melibatkan peran siswa secara aktif adalah model pembelajaran kooperatif tipe TGT (Teams Games Tournanent) karena dalam penerapan model pembelajaran kooperatif tipe TGT ini, siswa menempati posisi sangat dominan dalam proses pembelajaran dan terjadinya kerjasama dalam kelompok dengan ciri utama adanya permainan atau gamessehingga semua siswa berusaha untuk memahami setiap materi yang diajarkan dan bertanggung jawab atas game tournament yang dilakukan (Suyatno, 2009).

Untuk menjadikan siswa termotivasi dan aktif dalam belajar serta proses pembelajaran dapat berjalan dengan baik sesuai dengan yang diharapkan, maka salah satu cara yang dilakukan guru agar siswa menjadi termotivasi untuk belajar membaca yaitu dengan menerapkan model pembelajaran kooperatif tipe TGT dengan bantuan media kartu kata yang nantinya dapat diharapkan untuk menumbuhkan motivasi dan minat belajar siswa terutama dalam pelajaran membaca. Diharapkan dengan adanya model dan media ini siswa dapat bergairah dalam belajar.Untuk itu, dalam memilih model dan media yang akan digunakan hendaknya harus disesuaikan dengan tingkat kemampuan siswa, sehingga dalam proses pembelajaran menjadi lebih kondusif.

Berdasarkan pemikiran di atas, maka peneliti tertarik untuk melakukan suatu penelitian yang berjudul "Penerapan Model Pembelajaran Kooperatif Tipe TGT (Teams Games Tournament) dengan Media Kartu Kata dalam Pembelajaran Bahasa Indonesia untuk Meningkatkan Motivasi Belajar dan Kemampuan Membaca pada Siswa Kelas II Semester II di SD No. 2 Penarukan”.

\section{Metode}

Jenis penelitian ini dirancang dengan menggunakan jenis Penelitian Tindakan Kelas (Classroom Action Research). Menurut Arikunto, dkk (2007) penelitian tindakan kelas merupakan suatu pencermatan terhadap kegiatan belajar berupa sebuah tindakan, yang sengaja dimunculkan dan terjadi di sebuah kelas bersama. Dalam definisinya, Arikunto menekankan bahwa penelitian tindakan kelas merupakan suatu tindakan yang disengaja dimunculkan di kelas dan masalah tersebut perlu diadakan penelitian.Berdasarkan definisi yang dikemukakan di atas, penelitian tindakan kelas merupakan suatu penelitian yang diawali oleh adanya permasalahan yang muncul yang terjadi di kelas dan permasalahan tersebut memerlukan adanya tindakan lebih lanjut guna meningkatkan mutu pembelajaran yang lebih baik.

Dalam penelitian yang akan dilakukan, maka peneliti mengambil sebuah subjek penelitian di SD No. 2 Penarukan yang melibatkan para siswa kelas II semester II dengan jumlah 30 orang yang terdiri dari 12 Laki-laki dan 18 perempuan. Objek penelitian ini adalah meningkatkan motivasi belajar dan kemampuan membaca dengan menerapkan model pembelajaran kooperatif tipe TGT (Teams Games Tournament) dengan media kartu kata pada siswa kelas II semester II SD No. 2 Penarukan.Variabel yang dilibatkan adalah sebagai berikut: 1) Variabel Bebas, Yang merupakan variabel bebas dalam penelitian ini adalah penerapan model pembelajaran kooperatif tipe TGT (Teams Games Tournament) dan media kartu kata; 2) Variabel Terikat, Yang merupakan variabel terikat dalam penelitian ini adalah motivasi belajar dan kemampuan membaca.

Penelitian ini adalah penelitian tindakan kelas (PTK) yaitu bentuk penelitian yang bersifat reflektif dengan melakukan tindakan-tindakan tertentu untuk memperbaiki dan meningkatkan praktikpraktik pembelajaran di kelas secara professional (Suyanto,dkk, 1996).Penelitian tindakan kelas ini direncanakan melalui dua siklus. Setiap siklus menggunakan model pendekatan yang dikemukakan oleh Kemmis dan Mc Taggar, 1988 yang pelaksanaannya terdiri dari 4 tahap yaitu: (1). perencanaan tindakan, (2). pelaksanaan tindakan, (3). observasi/evaluasi, (4). refleksi. Siklus tersebut dapat digambarkan sebagai berikut. 


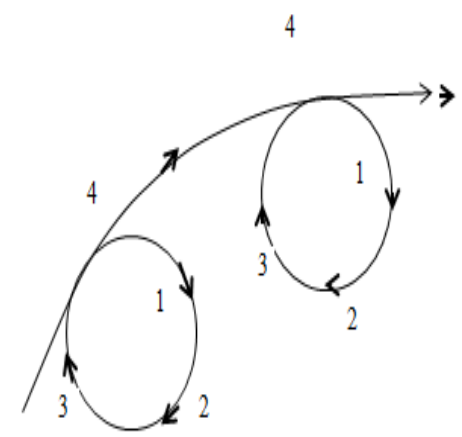

Gambar 2. Model PTK Dua Siklus (Kemis \& Mc. Taggart, 1998)

Penelitian tindakan kelas, dalam hal ini dilakukan beberapa kegiatan yaitu refleksi awal dan pelaksanaan tindakan. Berikut ini akan diuraikan secara lebih mendetail mengenai masing-masing kegiatan tersebut. Refleksi awal, Kegiatan refleksi awal ini meliputi wawancara dan observasi kelas dengan guru kelas II di SD No. 2 Penarukan.Observasi dan wawancara dilaksanakan untuk memperoleh gambaran yang lebih jelas mengenai masalah yang dihadapi di sekolah bersangkutan yang terkait dengan pembelajaran Bahasa Indonesia.Hasil wawancara dan observasi kelas telah diuraikan pada latar belakang.Berdasarkan hasil wawancara dan observasi kelas selanjutnya diperoleh kesepakatan mengenai tindakan yang akan dilakukan terkait dengan permasalahan yang dihadapi di kelas tersebut. Dari diskusi tersebut didapat suatu kesepakatan bahwa untuk memecahkan masalah seperti yang diuraikan di atas, maka akan dilaksanakan penerapan model pembelajaran kooperatif tipe TGT bermediakan kartu kata. Dalam penelitian ini dilaksanakan suatu tindakan yang terbagi menjadi dua siklus.Adapun tindakan yang dilaksanakan pada tiap siklus adalah sebagai berikut.

Siklus I, Dalam siklus I ini dilakukan beberapa kegiatan sebagai berikut: Perencanaan Tindakan, Perencanaan merupakan proses yang dilakukan untuk mempersiapkan segala sesuatu dalam pelaksanaan penelitian, yang meliputi: 1) Menentukan tema yang akandilibatkan dalam penelitian ini; 2) Menyusun persiapan mengajar. Persiapan mengajar ini merupakan salah satu bagian dari program pembelajaran yang memuat satuan bahasan untuk disajikan dalam tiga kali pertemuan. Rencana pembelajaran berfungsi sebagai acuan guru untuk melaksanakan proses belajar mengajar; 3) Menyiapkan media pembelajaran yang sesuai dengan tema untuk memperlancar jalannya proses pembelajaran yaitu berupa media kartu kata; 4) Menyusun alat evaluasi

Tabel 2. Skenario Pembelajaran Tindakan Siklus I (Pertemuan I, II dan III)

Guru
Pendahuluan
1. Membuka pelajaran dengan mengucapkan salam,
mengabsen siswa, mengisi jurnal kelas dan
menciptakan suasana kelas yang kondusif
2. Menyampaikan Standar Kompetensi yaitu,
Memahami ragam wacana tulis dengan membaca
nyaring dan membaca dalam hati. Kompetensi Dasar
(KD) yang akan dicapai hari itu adalah Membaca
teks pendek 15-20 kalimat dengan memperhatikan
lafal dan intonasi yang tepat, menyampaikan materi
dan tujuan pembelajaran, memotivasi kelas dan
memberikan apersepsi yang berkaitan dengan tema
dan materi pelajaran yang diberikan.

Inti

\section{Eksplorasi}

1. memberikan penjelasan singkat tentang kegiatan yang akan dilakukan.

2. Membentuk siswa menjadi beberapa kelompok .

3. Memfasilitasi siswa dengan LKS dan media

\section{Siswa}

1. Membalas salam memberi informasi temannya yang tidak masuk

2. Mendengarkan dengan seksama, mempersiapkan diri untuk menerima pembelajaran yang diberikan dan menanggapi pertanyaaan dari guru.

1. Memikirkan tentang kegiatan yang diberikan oleh guru dan membaca wacana dalam hati

2. Mengelompokkan diri menjadi beberapa kelompok dengan anggota 4-5 orang.

3. Menerima LKS dan media kartu 


Guru
pembelajaran.
4. Menyampaikan informasi tentang aturan permainan
(games) dan tournament

\section{Elaborasi}

1. Guru membimbing siswa dalam menggunakan media kartu kata dengan baik dan benar.

2. Guru menugaskan siswa melakukan suatu permainan dan turnamen untuk menjawab soal-soal yang dalam LKS dengan menggunakan media kartu kata.

3. Memberikan kesempatan kepada siswa untuk menyampaikan hasil diskusinya

\section{Konfirmasi}

1. memberikan umpan balik terhadap proses pembelajaran yang telah berlangsung.

2. Memberi penghargaan kepada kelompok yang terbaik dan memberi penguatan kepada siswa yang belum berhasil serta guru memotivasi siswa untuk tetap semangat belajar.

\section{Penutup}

1. Merangkum materi pelajaran bersama siswa.

2. Siswa melakukan refleksi terhadap kegiatan yang sudah dilaksanakan.

3. Guru memberi tindak lanjut berupa PR dan menutup pelajaran dengan salam

\section{Siswa}

kata yang dibagikan oleh guru dalam kelompoknya masingmasing.

4. Mendengarkan dengan seksama, mempersiapkan diri untuk menerima pembelajaran yang diberikan.

1. Siswa menyimak penjelasan guru tentang cara penggunaan media kartu kata.

2. Siswa mengerjakan perintah guru untuk melakukan permainan dan turnamen dalam mengerjakan soal-soal yang ada dalam LKS dengan bantuan media kartu kata yang tersedia.

3. Siswa menyampaikan hasil diskusinya.

1. Siswa merespon balikan terhadap pembelajaran yang berlangsung.

2. Siswa termotivasi untuk semangat belajar.

1. Membuat rangkuman

2. Mengadakan refleksi

3. Mencatat tugas yang diberikan guru dan membalas salam guru.

Tabel 3 Skenario Pembelajaran Tindakan Siklus II (Pertemuan I, II dan III)

Guru
Pendahuluan
1. Membuka pelajaran dengan mengucapkan salam,
mengabsen siswa, mengisi jurnal kelas dan
menciptakan suasana kelas yang kondusif
2. Menyampaikan Standar Kompetensi yaitu,
Memahami ragam wacana tulis dengan membaca
nyaring dan membaca dalam hati. Kompetensi
Dasar (KD) yang akan dicapai hari itu adalah
Menyebutkan isi teks agak panjang (20-25) kalimat
dibaca dalam hati, menyampaikan materi dan
tujuan pembelajaran, memotivasi siswa,
memberikan apersepsi yang berkaitan dengan tema
dan materi pelajaran yang diberikan.

\section{Inti}

\section{Eksplorasi}

1 memberikan penjelasan singkat tentang kegiatan yang akan dilakukan.

2 Membentuk siswa menjadi beberapa kelompok.
Siswa

1. Membalas salam memberi informasi temannya yang tidak masuk

2. Mendengarkan dengan seksama, mempersiapkan diri untuk menerima pembelajaran yang diberikan dan menanggapi pertanyaaan dari guru.

1. Memikirkan tentang kegiatan yang diberikan oleh guru dan membaca wacana dalam hati

2. Mengelompokkan diri menjadi beberapa kelompok dengan 


Guru
3 Memfasilitasi siswa dengan LKS dan media
pembelajaran.
4 menyampaikan informasi tentang aturan
permainan (games) dan tournament

\section{Elaborasi}

1 Guru membimbing siswa dalam menggunakan media kartu kata dengan baik dan benar.

2 Guru menugaskan siswa melakukan suatu permainan dan turnamen untuk menjawab soalsoal yang dalam LKS dengan menggunakan media kartu kata.

3 Memberikan kesempatan kepada siswa untuk menyampaikan hasil diskusinya

\section{Konfirmasi}

1 memberikan umpan balik terhadap proses pembelajaran yang telah berlangsung.

2 Memberi penghargaan kepada kelompok yang terbaik dan memberi penguatan kepada siswa yang belum berhasil serta guru memotivasi siswa untuk tetap semangat belajar.

\section{Penutup}

1. Merangkum materi pelajaran bersama siswa.

2. Siswa melakukan refleksi terhadap kegiatan yang sudah dilaksanakan.

3. Guru member tindak lanjut berupa PR dan menutup pelajaran dengan salam

\section{Siswa}

anggota 4-5 orang.

3. Menerima LKS dan media kartu kata yang dibagikan oleh guru dalam kelompoknya masingmasing.

4. Mendengarkan dengan seksama, mempersiapkan diri untuk menerima pembelajaran yang diberikan.

1. Siswa menyimak penjelasan guru tentang cara penggunaan media kartu kata.

2. Siswa mengerjakan perintah guru untuk melakukan permainan dan turnamen dalam mengerjakan soal-soal yang ada dalam LKS dengan bantuan media kartu kata yang tersedia.

3. Siswa menyampaikan hasil diskusinya.

1. Siswa merespon balikan terhadap pembelajaran yang berlangsung.

2. Siswa termotivasi untuk semangat belajar.

1. Membuat rangkuman

2. Mengadakan refleksi

3. Mencatat tugas yang diberikan guru dan membalas salam guru.

Pelaksanaan Tindakan, Pada tahap pelaksanaan tindakan ini, peneliti melaksanakan pembelajaran berdasarkan rencana pembelajaran yang telah disusun pada tahap perencanaan yaitu pembelajaran yang mengacu pada penerapan model pembelajaran kooperatif tipe TGT bermediakan kartu kata.Sebagai pelaksanaan tindakan dan sebagai observer, maka langkah-langkahnya adalah sebagai berikut: a) Melakukan sosialisasi tentang cara belajar dan model pembelajar yang dilaksanakan pada siswa serta sistem evaluasi yang digunakan pada awal kegiatan; b) Membagi siswa dalam kelompokkelompok kecil itu yang berjumlah 4-5 orang, sebanyak 6 (enam) kelompok; c) Melaksanakan kegiatan pembelajaran dengan model pembelajaran kooperatif tipe TGT (Teams Games Tournament)dengan media kartu kata yang mengacu pada pemahaman konsep, penalaran dan komunikasi. Langkah-langkah pembelajaran adalah sebagai berikut: a) Memberikan kesempatan kepada siswa untuk berdiskusi mengenai cara merangkai kartu kata menjadi sebuah kalimat pendek; b) Memberikan kesempatan kepada siswa untuk menyampaikan hasil diskusi kelompok termasuk mengungkapkan pertanyaan atau memberi tanggapan terhadap pendapat yang muncul.Menyimpulkan kegiatan butir (a) dan (b), serta memperbaiki kesalahan-kesalahan konsepsi siswa dan memberikan masukan tentang konsep-konsep yang belum dipahami siswa.

Observasi/Evaluasi, Kegiatan observasi/evaluasi yang dilakukan oleh peneliti untuk melihat kegiatan yang dilakukan oleh siswa selama pembelajaran berlangsung. Adapun hal-hal yang diamati adalah sebagai berikut: a) Kegiatan yang dilakukan oleh siswa pada saat melakukan diskusi, permainan dan turnamen mengenai cara merangkai kartu kata menjadi sebuah kalimat pendek; b) Mengamati hambatan-hambatan yang dihadapi oleh siswa selama pembelajaran berlangsung; c) Mengevaluasi tindakan siswa berdasarkan tes yang telah dilakukan pada akhir siklus I. 
Refleksi, Pada akhir siklus I ini refleksi dilakukan untuk melihat, mengkaji dan mempertimbangkan dampak tindakan yang telah dilaksanakan. Berdasarkan hasil refleksi ini, peneliti bersama-sama guru dapat melakukan perbaikan kekurangan-kekurangan dalam proses pembelajaran. Kegiatan yang dilakukan pada rancangan refleksi ini adalah peneliti mengkaji dan merenungkan hasil penilaian terhadap pelaksanaan tindakan tersebut dengan maksud jika terjadi hambatan, akan dicari pemecahan masalahnya untuk direncanakanpada siklus II.Siklus II, Kegiatan yang dilakukan pada siklus II ini pada prinsipnya sama dengan kegiatan pada siklus I. hanya saja, pada siklus ini tindakan yang dilaksanakan adalah berupa tindakan yang merupakan hasil penyempurnaan dari tindakan yang dilaksanakan pada siklus I. Sehingga tindakan pada siklus II pada dasarnya telah mengalami penyempurnaan, dengan demikian diharapkan telah mampu mencapai tujuan yang dicanangkan pada penelitian ini. Dengan kata lain, semua permasalahan yang dirumuskan diatas telah dipecahkan. Pada akhir siklus II ini akan dilakukan suatu reflekksi akhir guna merumuskan hasil dari semua kegiatan yang dilaksanakan dalam penelitian ini.

Data motivasi belajar siswa dikumpulkan dengan menggunakan angket motivasi belajar. Dalam angket tersebut terdapat pernyataan dengan masing-masing 5 pilihan yaitu selalu (SL), Sering (SR), kadang-kadang (KK), jarang (JR), tidak pernah (TP). Pemberian skor pada setiap item $S L=5, S R=4, K K=3$, $J R=2, T P=1$ untuk pernyaataan positif. Dan untuk pernyataan negatif diberi skor $S L=1, S R=2, K K=3, J R=4$, $\mathrm{TP}=5$. Skor respon siswa diperoleh dengan menjumlahkan skor yang diperoleh siswa untuk setiap item.Berikut disajikan contoh bentuk instrumen pengumpulan data tentang motivasi belajar.

Tabel 4. Angket Motivasi Belajar Bahasa Indonesia Siswa

\begin{tabular}{|c|c|c|c|c|c|c|}
\hline \multirow{2}{*}{ No } & \multirow{2}{*}{ Pernyataan } & \multicolumn{5}{|c|}{ Tanggapan } \\
\hline & & SL & SR & KK & $\mathrm{JR}$ & $\mathrm{TP}$ \\
\hline 1. & $\begin{array}{l}\text { Saya mengikuti pelajaran di kelas dengan sungguh- } \\
\text { sungguh. }\end{array}$ & & & & & \\
\hline 2. & $\begin{array}{l}\text { Saya malu untuk menanyakan penjelasan guru yang } \\
\text { kurang saya pahami. }\end{array}$ & & & & & \\
\hline 3. & $\begin{array}{l}\text { Saya selalu bermain-main dalam mengikuti pelajaran di } \\
\text { kelas. }\end{array}$ & & & & & \\
\hline 4. & $\begin{array}{l}\text { Saya belajar dan mencari tahu dari sumber-sumber } \\
\text { lain. }\end{array}$ & & & & & \\
\hline 5. & $\begin{array}{l}\text { Di rumah saya lebih senang nonton TV dari pada } \\
\text { belajar. }\end{array}$ & & & & & \\
\hline 6. & $\begin{array}{l}\text { Saya terpaksa menyelesaikan tugas belajar karena takut } \\
\text { mendapat hukuman. }\end{array}$ & & & & & \\
\hline 7. & $\begin{array}{l}\text { Saya mengerjakan pekerjaan rumah dengan melihat } \\
\text { pekerjaan orang lain. }\end{array}$ & & & & & \\
\hline 8. & $\begin{array}{l}\text { Tugas-tugas yang menjadi tanggung jawab saya, saya } \\
\text { kerjakan sebaik-baiknya. }\end{array}$ & & & & & \\
\hline 9. & $\begin{array}{l}\text { Untuk memperoleh hasil belajar yang bagus, saya } \\
\text { mengulangi pelajaran sehingga saya mengerti. }\end{array}$ & & & & & \\
\hline 10. & Setiap hari saya meluangkan diri untuk membaca buku. & & & & & \\
\hline
\end{tabular}

\section{Hasil Dan Pembahasan}

Pelaksanaan pembelajaran di dalam kelas selama ini secara umum telah berlangsung sesuai dengan rencana pembelajaran yang telah disusun sebelumnya. Penelitian ini dilaksanakan dalam 2 siklus, dimana setiap siklus dilaksanakan dalam 3 kali pertemuan. Data yang dikumpulkan dalam penelitian ini, yaitu data tentang peningkatan motivasi belajar dan kemampuan membaca siswa terhadap pembelajaran yang dilaksanakan. Data yang telah dikumpulkan dianalisis sesuai dengan teknik analisis data yang telah ditetapkan sebelumnya. Adapun hasil dari analisis data mengenai data tentang peningkatan kemampuan membaca siswa terhadap pembelajaran yang dilaksanakan akan dijelaskan sebagai berikut. Kenyataan di lapangan menunjukkan bahwa motivasi belajar dan kemampuan membaca siswa masih rendah, hal ini dapat dilihat dari hasil observasi data awal siswa pada mata pelajaran Bahasa Indonesia yang dilakukan terhadap siswa kelas II Semester II di SD No. 2 Penarukan.Ditemukan bahwa dari 30 siswa kelas II, hanya 12 orang yang menunjukkan kemampuan membaca permulaan yang sudah memenuhi kriteria keberhasilan. Namun kemampuan membaca permulaan siswa lainnya masih belum memenuhi kriteria 
keberhasilan, itu terlihat dari nilai kemampuan membaca siswa masih di bawah rata-rata atau belum memenuhi standar KKM (Kriteria ketuntasan Minimal) yang ditentukan.

Berdasarkan analisis data dapat dilihat bahwa motivasi belajar Bahasa Indonesia siswa pada akhir siklus I belum memenuhi kategori yang ditetapkan yaitu sebesar 30,83, berada pada kategori "cukup tinggi" . Indikator keberhasilan motivasi belajar Bahasa Indonesia siswa dalam penelitian ini yaitu apabila motivasi belajar Bahasa Indonesia siswa minimal berada pada kategori "tinggi" baik secara individu maupun klasikal. Peningkatan kemampuan membaca siswa secara klasikal yang dilakukan pada siklus I adalah 65,86. Bila dikonversikan dengan kreteria peningkatan kemampuan membaca siswa terletak pada

rentangan 58,33 $\leq \overline{\mathrm{X}}<75,05$ termasuk predikat "tinggi", namun peningkatan kemampuan membaca siswa secara individu belum memenuhi kriteria keberhasilan. Indikator keberhasilan peningkatan kemampuan membaca siswa dalam penelitian ini yaitu apabila kemampuan membaca siswa minimal berada pada kategori "tinggi" baik secara individu maupun klasikal.

Agar peningkatan motivasi belajar dan kemampuan membaca siswa dapat tercapai secara maksimal pada siklus berikutnya, maka segala kekurangan yang terjadi selama proses pembelajaran pada siklus I dilakukan penyempurnaan dalam menggunakan model dan media pembelajaran agar peningkatan membaca pada siswa dapat meningkat. Adapun kendala-kendala yang ditemukan pada siklus I diantaranya: (1) jumlah kartu kata yang masih terbatas, sehingga siswa kurang aktif dalam pembelajaran, (2) penerapan model pembelajaran kooperatif tipe TGT belum bisa secara maksimal diterapkan dan dalam pembelajaran sebagian siswa masih cenderung pasif dan tidak memperhatikan apa yang sedang dijelaskan.

Berdasarkan kendala-kendala yang ditemukan pada siklus I, maka perlu dilakukan penyempurnaan dalam pelaksanaan siklus selanjutnya yakni (1) memperbanyak jumlah kartu kata dalam pembelajaran, (2) dalam pembelajaran guru/peneliti menerapkan model pembelajaran secara maksimal serta mengawasi dan memberikan bimbingan kepada setiap siswa sehingga pembelajaran menjadi lebih menarik dan bermakna.

Pada siklus II peningkatan motivasi belajar siswa secara klasikal adalah sebesar 39,77. Bila dikonversikan terletak pada kategori "tinggi" dan juga peningkatan motivasi siswa secara individu sudah memenuhi kriteria keberhasilan yaitu semua siswa sudah memperoleh nilai dengan kategori "tinggi". Bila dibandingkan dengan hasil peningkatan motivasi belajar siswa pada siklus I, maka terjadi peningkatan dari siklus I ke siklus II sebesar 8,94. Begitu pula dengan peningkatan kemampuan membaca pada siswa secara klasikal adalah sebesar 72,13. Bila dikonversikan dengan kreteria peningkatan kemampuan membaca siswa terletak pada rentangan 58,33 $\leq \bar{X}_{<}$75,05 termasuk predikat "tinggi" dan juga peningkatan kemampuan membaca siswa secara individu sudah memenuhi kriteria keberhasilan yaitu semua siswa sudah memperoleh nilai dengan kategori "tinggi". Bila dibandingkan dengan hasil peningkatan kemampuan membaca pada siklus I, maka terjadi peningkatan kemampuan membaca dari siklus I ke siklus II sebesar 6,27. Dengan meningkatnya motivasi belajar dan kemampuan membaca siswa melalui penerapan model pembelajaran kooperatif tipe TGT (Teams Games Tournament) dengan media kartu kata dalam pembelajaran bahasa indonesia, maka guru harus ikut memperhatikan perkembangan motivasi belajar siswa dan kemampuan membaca siswa, terutama pada siswa yang mengalami kesulitan belajar membaca.

Berdasarkan uraian di atas dapat ditarik kesimpulan bahwa penerapan model pembelajaran kooperatif tipe TGT (Teams Games Tournament) dengan media kartu kata dapat meningkatkan motivasi belajar dan kemampuan membaca permulaan pada siswa kelas II semester II SD No. 2 Penarukan. Oleh sebab itu strategi pembelajaran yang demikian sangat perlu dilakukan secara intensif dan berkelanjutan Karena motivasi dalam belajar dan kemampuan membaca sangat penting bagi anak untuk perkembangan selanjutnya. Dengan motivasi belajar yang tinggi siswa akan dapat meningkatkan kemampuan membacanya dengan baik, sehingga anak akan mudah untuk berkomunikasi dengan lingkungannya.

\section{Simpulan Dan Saran}

Berdasarkan analisis data dapat dilihat bahwa motivasi belajar Bahasa Indonesia siswa pada akhir siklus I belum memenuhi kategori yang ditetapkan yaitu sebesar 30,83, berada pada kategori "cukup tinggi" . Indikator keberhasilan motivasi belajar Bahasa Indonesia siswa dalam penelitian ini yaitu apabila motivasi belajar Bahasa Indonesia siswa minimal berada pada kategori "tinggi" baik secara individu maupun klasikal. Peningkatan kemampuan membaca siswa secara klasikal yang dilakukan pada siklus I adalah 65,86. Bila dikonversikan dengan kreteria peningkatan kemampuan membaca siswa terletak pada rentangan 58,33 $\leq \bar{X}<75,05$ termasuk predikat "tinggi", namun peningkatan kemampuan membaca siswa secara individu belum memenuhi kriteria keberhasilan. Indikator keberhasilan peningkatan 
kemampuan membaca siswa dalam penelitian ini yaitu apabila kemampuan membaca siswa minimal berada pada kategori "tinggi" baik secara individu maupun klasikal.

Agar peningkatan motivasi belajar dan kemampuan membaca siswa dapat tercapai secara maksimal pada siklus berikutnya, maka segala kekurangan yang terjadi selama proses pembelajaran pada siklus I dilakukan penyempurnaan dalam menggunakan model dan media pembelajaran agar peningkatan membaca pada siswa dapat meningkat. Adapun kendala-kendala yang ditemukan pada siklus I diantaranya: (1) jumlah kartu kata yang masih terbatas, sehingga siswa kurang aktif dalam pembelajaran, (2) penerapan model pembelajaran kooperatif tipe TGT belum bisa secara maksimal diterapkan dan dalam pembelajaran sebagian siswa masih cenderung pasif dan tidak memperhatikan apa yang sedang dijelaskan.

Berdasarkan kendala-kendala yang ditemukan pada siklus I, maka perlu dilakukan penyempurnaan dalam pelaksanaan siklus selanjutnya yakni (1) memperbanyak jumlah kartu kata dalam pembelajaran, (2) dalam pembelajaran guru/peneliti menerapkan model pembelajaran secara maksimal serta mengawasi dan memberikan bimbingan kepada setiap siswa sehingga pembelajaran menjadi lebih menarik dan bermakna.

Pada siklus II peningkatan motivasi belajar siswa secara klasikal adalah sebesar 39,77. Bila dikonversikan terletak pada kategori "tinggi" dan juga peningkatan motivasi siswa secara individu sudah memenuhi kriteria keberhasilan yaitu semua siswa sudah memperoleh nilai dengan kategori "tinggi". Bila dibandingkan dengan hasil peningkatan motivasi belajar siswa pada siklus I, maka terjadi peningkatan dari siklus I ke siklus II sebesar 8,94. Begitu pula dengan peningkatan kemampuan membaca pada siswa secara klasikal adalah sebesar 72,13. Bila dikonversikan dengan kreteria peningkatan kemampuan membaca siswa terletak pada rentangan 58,33 $\leq \bar{X}<75,05$ termasuk predikat "tinggi" dan juga peningkatan kemampuan membaca siswa secara individu sudah memenuhi kriteria keberhasilan yaitu semua siswa sudah memperoleh nilai dengan kategori "tinggi". Bila dibandingkan dengan hasil peningkatan kemampuan membaca pada siklus I, maka terjadi peningkatan kemampuan membaca dari siklus I ke siklus II sebesar 6,27. Dengan meningkatnya motivasi belajar dan kemampuan membaca siswa melalui penerapan model pembelajaran kooperatif tipe TGT (Teams Games Tournament) dengan media kartu kata dalam pembelajaran bahasa indonesia, maka guru harus ikut memperhatikan perkembangan motivasi belajar siswa dan kemampuan membaca siswa, terutama pada siswa yang mengalami kesulitan belajar membaca.

Berdasarkan uraian di atas dapat ditarik kesimpulan bahwa penerapan model pembelajaran kooperatif tipe TGT (Teams Games Tournament) dengan media kartu kata dapat meningkatkan motivasi belajar dan kemampuan membaca permulaan pada siswa kelas II semester II SD No. 2 Penarukan. Oleh sebab itu strategi pembelajaran yang demikian sangat perlu dilakukan secara intensif dan berkelanjutan Karena motivasi dalam belajar dan kemampuan membaca sangat penting bagi anak untuk perkembangan selanjutnya. Dengan motivasi belajar yang tinggi siswa akan dapat meningkatkan kemampuan membacanya dengan baik, sehingga anak akan mudah untuk berkomunikasi dengan lingkungannya.

\section{Daftar Pustaka}

Arikunto, Suharsimi. (1993). Manajemen Pengajaran Secara Manusiawi. Jakarta: PT. Rineka Cipta.

Depdikbud, (1997). Materi Pokok Pembelajaran Terpadu D-II PGSD. Jakarta: Ditjen Dikti.

Depdiknas, (2003). Pendekatan Kontekstual (Contextual Teacing and Learning). Jakarta: Direktorat Pendidikan Dasar dan Direktorat Pendidikan Lanjut.

Hairuddin, dkk. (2008). Pembelajaran Bahasa Indonesia. Direktorat Jendral Pendidikan Tinggi Departeman Pendidikan Nasional.

Hamalik, Oeamar. 1986. Media Pendidikan. Bandung: Alumni.

Kemmis, Stephen \& Taggrat, Robin Mc. (1998). The Action Research Planner. Victoria: Deakin University.

Kotha, Made. (2003). Meningkatkan Kemampuan Membaca Permulaan Dengan Menggunakan Kartu Huruf Dan Media Gambar Pada Anak Kelas I Sekolah Dasar Negeri Subuk, Kecamatan Busungbiu, Kabupaten Buleleng Tahun Ajaran 2003/2004.

Lie, A. (2004). Cooperative Learning: Mempraktikkan Cooperative Learning di Ruang Kelas. Jakarta: Grasindo.

Nasution, S. (1986). Didaktik Asas-Asas Mengajar. Bandung: Jemars. 
Natawidjaja, Rochman dan Moein Moesa. (1991). Psikologi Pendidikan. Jakarta: Departemen Pendidikan Nasional.

Nurkancana, wayan dan Sunartana. (1990). Evaluasi Hasil Belajar. Surabaya: Usaha Nasional.

Purwanto, M. dan Jeniah Alim. (1997). Metodologi Pengajaran Bahasa Indonesia diSekolah Dasar. Jakarta: PT. Roesda Jayaputra.

Sardiman. (2007). Interaksi dan Motivasi Belajar Mengajar. Jakarta: PT RajaGrafindo Persada.

Slavin, Robert. (2008). Cooperative Learning, Teori, Riset dan Praktik.Bandung: Nusa Media.

Suarnaya, ketut. (2003). Meningkatkan Kemampuan Membaca Dan Menulis Permulaan Pada Pembelajaran Bahasa Indonesia Melalui Penerapan Media Belajar Kartu Kata Pada Siswa Kelas II Semester I Sekolah Dasar NO 5 Sembiran Tahun Pelajaran 2003/2004.

Subana, M. Et. al. (2000). Strategi belajar Mengajar Bahasa Indonesia. Bandung: Pusaka Setia.

Sudarma,I Komang dan Parmiti, Desak Putu. (2007). Media Pembelajaran. Singaraja: Undiksha.

Sudiantara, I Kadek. 2009. Penggunaan Media Kartu Suku Kata dalam Pembelajaran Bahasa Indonesia untuk Meningkatkan Kemampuan Membaca Permulaan Siswa Kelas I Semester I SD Negeri 3 Menanga, Kecamatan Rendang, Kabupaten Karangasen. Skripsi (tidak diterbitkan). Jurusan PGSD, Universitas Pendidikan Ganesha Singaraja.

Sumantri, Iwan. (2008). Dua Model Pembelajaran yang Inovatif. http://iwansmtri.blogspot.com/2009/01/dua-model-pembelajaran-inovatif.html. diakses tanggal 25 Desember 2009.

Suryanti, Ni Nengah Tunjung. (2009). Penerapan Pembelajaran Kooperatif dengan Model TGT untuk Meningkatkan Motivasi dan Prestasi Belajar IPA pada Siswa Kelas V SD N 1 Kubu.Skripsi (tidak diterbitkan). Jurusan PGSD, Universitas Pendidikan Ganesha Singaraja.

Suyatno. (2009). Menjelajah Pembelajaran Inovatif. Sidoarjo: Masmedia Buana Pustaka.

Tarigan, Hendry Guntur. (1986). Menyimak Sebagai Suatu Keterampilan. Bandung: Angkasa.

Tarigan, Hendry Guntur. (1989). Membaca Sebagai Suatu Keterampilan. Bandung: Angkasa.

Tegeh, I Made. (2008). Media Pembelajaran. Malang: Universitas Negeri Malang.

Trianto. (2007). Model-Model Pembelajaran Inovatif Berorientasi Konstruktivistik. Jakarta: Prestasi Pustaka 